\title{
Flipped Classroom for Diving Environment Training Using Cooperative Learning
}

\author{
Egi Wikanda \\ Educational Technology, Universitas Negeri Jakarta, Jakarta, Indonesia \\ e-mail:egiw230283@gmail.com \\ Eveline Siregar \\ Educational Technology, Universitas Negeri Jakarta, Jakarta, Indonesia \\ e-mail:esiregar@unj.ac.id \\ RA Murti Kusuma Wirasti \\ Educational Technology, Universitas Negeri Jakarta, Jakarta, Indonesia \\ e-mail:murti@unj.ac.id
}

\section{A R T I C L E I N F O \\ Article history: \\ 25 December 2020 \\ Received in revised form \\ 01 January 2021 \\ Accepted 25 January 2021 \\ Available online 03 Pebruari 2021

Kata Kunci:
Kelas Terbalik, Latihan,
Menyelam, Pembelajaran
Kooperatif.
Keywords:
Flipped Classroom,
Training, Dive, Cooperative
Learning

\begin{abstract}
A B S T R A K
Pelatihan diving di Basarnas terkendala jarak sehingga berdampak pada kinerja tugas pegawai sebagai individu. Penelitian ini bertujuan untuk mengembangkan ruang kelas terbalik untuk pelatihan lingkungan penyelaman bagi penyelamat dan mendapatkan hasil untuk menilai kelayakan mereka. Penelitian ini menghasilkan desain penelitian dan pengembangan pembelajaran dengan tahapan dan prosedur yaitu menggunakan desain pembelajaran berbasis multimedia dengan tahapan mulai dari asesmen dan analisis kebutuhan, perancangan, pengembangan, implementasi dan evaluasi. Teknik analisis data yang digunakan adalah analisis kualitatif dan kuantitatif. Langkah pengembangan yang dilakukan mengacu pada desain pembelajaran berbasis web yang dipadukan dengan model PEDATI pada tahap desain. Uji kelayakan diperoleh berdasarkan penilaian para ahli yang meliputi ahli materi, ahli desain pembelajaran dan ahli media serta pengujian bagi pengguna untuk mendapatkan saran perbaikan. Dari hasil penelitian didapatkan hasil evaluasi ahli materi diklat dengan nilai persentase total $94,79 \%$, validasi ahli desain pembelajaran $90,27 \%$, dan validasi ahli media pembelajaran 90,38\%. Hasil tes individual one-to-one disimpulkan sangat valid dan dapat digunakan tanpa revisi, dan untuk tes dalam kelompok kecil rata-rata penilaiannya sangat valid tanpa revisi. Dapat disimpulkan bahwa pembelajaran Flipped Classroom cocok
\end{abstract} digunakan dalam pelatihan lingkungan menyelam dengan menggunakan pembelajaran kooperatif.

\begin{abstract}
A B S T R A C T
Diving training at Basarnas is constrained by distance so that it has an impact on the performance of employees' duties as individuals. This study aims to develop a flipped classroom for diving environment training for rescuers and obtain results to assess their feasibility. This study produces a research design and learning development with steps and procedures, namely using a multimedia-based learning design with stages ranging from assessment and needs analysis, design, development, implementation and evaluation. The techniques used to analyze the data are qualitative and quantitative analysis. The development steps taken refer to the web-based learning design combined with the PEDATI model at the design stage. The feasibility test is obtained based on the assessment of experts including material experts, learning design experts and media experts as well as testing for users to get suggestions for improvement. From the results of this study, it was found that the evaluation of training material experts with a total percentage value of $94.79 \%$, expert validation of learning design $90.27 \%$, and validation by instructional media experts $90.38 \%$. The results of the individual one-to-one test are concluded to be very valid and can be used without revision, and for tests in small groups the average assessment is very valid without revision. It can be concluded that Flipped Classroom learning is suitable for use in diving environment training using cooperative learning.
\end{abstract}

\section{Introduction}

The development of science and technology in the 21 st century is happening very rapidly. This affects all aspects of life (Rochmad \& Ulinnuha, 2020; Wulandari, Sudatha, \& Simamora, 2020). This has also been said by Raditya \& Widhiyani (2018) which states that information technology which is currently developing very rapidly will bring changes to all aspects of life. In addition, the development of high-speed internet services has made significant progress in less than a decade (Soni et al., 2018; Yusny \& Yasa, 2019). This has made major changes to the educational aspect, especially the learning method. Currently, a person can study anywhere 
without having to take part in classroom learning (Kurtz, Tsimerman, \& Steiner, 2014; Yusuf \& Widyaningsih, 2018). The rapid development of technology makes it easier for a person to learn so that it can be used as a means to improve the quality of education. Producing quality human resources requires efforts to improve the quality of education (Hikmawati \& Fathan, 2019; Yayuk \& Sugiyono, 2019). one of the efforts that can be done by improving the learning process. technological advances can help improve learning activities.

The problem that has occurred recently is that many training institutions are constrained by distance. Based on the results of observations, several problems were found, namely the diving training at Basarnas has been constrained by the distance between the training institute and the employee's place which is quite far, and the time is limited to be used in training activities. This has an impact on the performance of employee duties as a person. Rescuers in carrying out SAR tasks by diving are less than optimal. Therefore, it is necessary to make learning development efforts in accordance with the characteristics of personnel competencies and of course the needs of the organization. Competence regarding the diving environment is very much needed by a rescuer in carrying out SAR operations in the marine environment, which is precisely under water by diving in various conditions. Besides having to have good knowledge, it is also supported by qualified skills. Training is a systematic process of providing opportunities to learn knowledge, skills and attitudes for current jobs or future challenges (Dahniar, 2019; Elizar \& Tanjung, 2018).

The combination of face-to-face and online learning can be a solution to the above problems. Blended learning is an activity combining learning delivery strategies using face-to-face activities, computer-based learning (offline), and online with the internet. (Ceylan, 2017; Purnomo, Ratnawati, \& Aristin, 2016; Wulandari et al., 2020). One of the class rotation models in blended learning is flipped classroom. Dziuban, Graham, Moskal, Norberg, \& Sicilia (2018) defines that flipped classroom learning is an approach to learning where instruction moves directly from the classroom learning room to individual study rooms, and produces group spaces in the classroom. This learning model creates a dynamic and interactive learning environment in which teachers guide students as they apply concepts and engage creatively in subject matter. (Fitriana, 2017; Kalantarrashidi, Mohammadpour, \& Sahraei, 2015). flipped classroom reverses the class that is traditionally done entirely outside the classroom (Usman, 2018). his can be combined with a cooperative learning approach, namely the application of strategies in a suitable pedagogical model. The cooperative learning approach has several principles in its application, namely, 1) Positive interdependence, by helping each other produce good teamwork, 2) Individual accountability, increasing individual competence which is the result of teamwork, 3) Equal Participants, based on the ability of each individual to have the same opportunity and workload, 4) Simultaneous interaction, groups both in pairs and teams have continuous intervals of relationships based on structure (Darmayasa, Suara, \& Manuaba, 2013; Megawati \& Riastini, 2014).

A study states that learning flipped classroom with a cooperative approach can improve student competence based on the learning outcomes obtained (Foldnes, 2016). This is of course supported by proper design procedures and steps, flipped classroom designs that can be used, one of which is by using the PEDATI model with the acronym learn, explore, apply and evaluate (Chaeruman, 2017). This model emphasizes activities in mixed learning with learning settings. in synchronous and asynchronous form (Wulandari et al., 2020). The technology used to facilitate online learning can be in the form of a network-based learning management system application as software used to document, manage, track, and report on training programs held electronically (Kamarga, 2018).

This study developed a flipped classroom model of online learning design with a cooperative learning approach. The purpose of this study is to develop a flipped classroom in a diving environment training for rescuers and obtain results to assess their feasibility. It is hoped that the flipped classroom learning model that uses cooperative learning can be used for training in a diving environment so that it can overcome time and distance limitations.

\section{Method}

This research is a learning design and development with steps and procedures, namely using a multimedia-based learning design with stages ranging from assessment and needs analysis, design, development, implementation and evaluation. (Lee \& Owens, 2004). The main focus of this research is the assessment and needs analysis, design and development stages. At the assessment and need analysis stage, a qualitative approach was carried out, namely by conducting interviews with officials in organizations in charge of managing technical personnel for search and rescue, training instructors, and employees as participants. The qualitative analysis technique used is an interactive data analysis model. After that, by doing a front-end analysis to ensure in more detail the appropriate needs for learning development.

Furthermore, at the design stage it will be combined with the PEDATI model as a description of learning activities, namely by formulating learning outcomes, describing the content of the material, designing synchronous and asynchronous learning activities and making cooperative flipped classroom learning schemes. 
After that, the instructional media design that is made will be used to be assembled into an application based on the Learning Management System platform. The development stage is to describe the contents of the learning media to produce an initial prototype which is then validated by experts consisting of material experts, learning design experts and instructional media experts, then perform user validation as part of development in order to obtain eligibility.

In this development research using several data analysis techniques based on the stages and stages of the data obtained, namely by a) Qualitative, using an interactive data model with condensation, display and verification. By processing the results of the data obtained through interviews, questionnaires, and the results of suggestions and input to be displayed based on the previous order conclusions were drawn after previously verifying the data obtained. b) Quantitative analysis, namely by converting the data obtained into percentages and scales. The validity of the score results from expert and user validation can refer to the table 1 .

Table 1. Validation value conversion scale (Akbar, 2013)

\begin{tabular}{cll}
\hline No & \multicolumn{1}{c}{ Validity Criteria } & \multicolumn{1}{c}{ Level of Validity } \\
\hline 1 & $85,01 \%-100,00 \%$ & Very valid, or can be used without revision \\
2 & $70,01 \%-85,00 \%$ & Quite valid, or can be used but needs minor revisions \\
3 & $50,01 \%-70,00 \%$ & Less valid, it is recommended not to use it because it needs \\
& & major revisions \\
4 & $01,00 \%-50,00 \%$ & Invalid, or may not be used \\
\hline
\end{tabular}

\section{Result and Discussion}

The results of interviews conducted with officials at the Directorate of Manpower Development, namely the Head of the Sub-Directorate for Planning and Personnel Standardization, resulted in a description of the need for training development, namely, One of the main tasks of rescuers and the field of operations, namely in the water area. Search and rescue operations of water areas are the activities most often carried out by rescuers because most of their territories are dominated by waters, including under water. One of the important competencies that must be mastered is being able to search and rescue underwater by diving. This competency is very specific which must be supported by qualified knowledge and skills. From the data, it was found that $60 \%$ of respondents did dives while on duty in the waters and the rest were on the surface of the water. In addition to the basics of diving that is mastered, it is necessary to understand the conditions of the underwater environment with the aim of preserving the environment and avoiding the dangers that threaten the rescuer while in the underwater diving environment. Based on the data obtained, only $30 \%$ of respondents have structured training. The problems that occur are due to the limited capacity of participants in training institutions, distances or training locations that are far away. coupled with the number of instructors who are still limited.

In terms of learning needs to use the internet, the respondent's data obtained from the total percentage of respondents more than $75 \%$ stated that they were accustomed to using technology, both hardware and software application menus connected to the internet. In the aspect of learning media, the response obtained was $80 \%$, which stated that teaching materials played a very important role in the learning process. In the learning strategy aspect, $88.9 \%$ of the respondents' data were obtained which stated that the application of group learning can be used and is suitable for technical training for rescuers. The current condition is that the training is still carried out face-to-face with the arrival of participants from all SAR agencies to be gathered at a centralized training center, with the instructor conveying concepts, theories, and procedures in class through demonstrations and interactions after which practice is carried out by dividing small groups according to learning material needs.

From the results of the analysis and needs assessment obtained, the design is carried out into learning outcomes, subject matter, material descriptions and separation of synchronous and asynchronous activities based on competency targets to achieve the expected training objectives.

Table 2. Achievements and Learning Activities

\begin{tabular}{|c|c|c|c|c|c|c|}
\hline \multirow{3}{*}{$\begin{array}{l}\text { Learning } \\
\text { outcomes }\end{array}$} & \multirow{3}{*}{ Subject } & & \multirow{3}{*}{ Sub Topics } & \multirow{3}{*}{ Subject matter } & \multicolumn{2}{|c|}{ Learning activities } \\
\hline & & & & & Sync & Asynchronous \\
\hline & & & & & SL SM & \\
\hline $\begin{array}{l}\text { Learners can } \\
\text { explain the }\end{array}$ & $\begin{array}{l}\text { Underwater } \\
\text { environment }\end{array}$ & 1. & $\begin{array}{l}\text { Underwater } \\
\text { environmental }\end{array}$ & $\begin{array}{l}\text { Underwater } \\
\text { conditions }\end{array}$ & & $\mathrm{V}$ \\
\hline underwater & & & conditions & Underwater life & & $\mathrm{V}$ \\
\hline $\begin{array}{l}\text { environment for } \\
\text { diving properly }\end{array}$ & & & $\begin{array}{l}\text { The role of } \\
\text { underwater }\end{array}$ & $\begin{array}{l}\text { The role of } \\
\text { underwater }\end{array}$ & & $\mathrm{V}$ \\
\hline
\end{tabular}




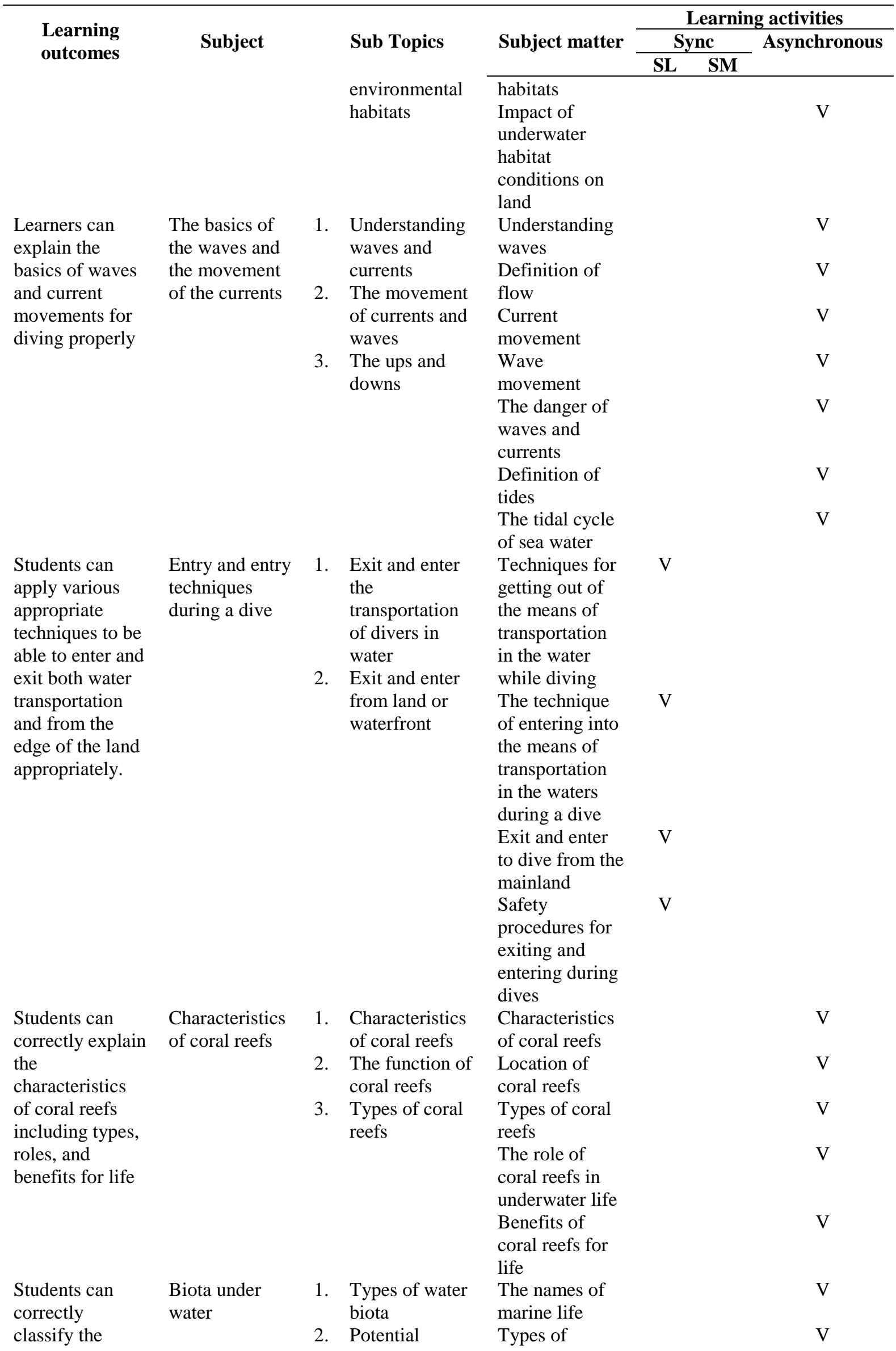




\begin{tabular}{|c|c|c|c|c|c|c|c|}
\hline \multirow{3}{*}{$\begin{array}{l}\text { Learning } \\
\text { outcomes }\end{array}$} & \multirow{3}{*}{ Subject } & & \multirow{3}{*}{ Sub Topics } & \multirow{3}{*}{ Subject matter } & \multicolumn{3}{|c|}{ Learning activities } \\
\hline & & & & & \multicolumn{2}{|c|}{ Sync } & \multirow[t]{2}{*}{ Asynchronous } \\
\hline & & & & & SL & $\mathbf{S M}$ & \\
\hline \multirow{22}{*}{$\begin{array}{l}\text { types of biota } \\
\text { under water, } \\
\text { especially in the } \\
\text { oceans, as well } \\
\text { as the potential } \\
\text { hazards for } \\
\text { divers } \\
\text { Students can } \\
\text { apply diving } \\
\text { techniques with } \\
\text { various } \\
\text { conditions under } \\
\text { water properly. }\end{array}$} & & & hazards to & marine life & & & \\
\hline & & & underwater & The nature of & & & V \\
\hline & & & biota & various marine & & & \\
\hline & & & & life & & & \\
\hline & & & & The dangers of & & & V \\
\hline & & & & marine life for & & & \\
\hline & & & & divers & & & \\
\hline & Diving & 1. & Use kicking & The kicking & V & & \\
\hline & techniques in & & techniques & technique while & & & \\
\hline & various & & when & diving is & & & \\
\hline & underwater & & performing & suitable for & & & \\
\hline & conditions & & search and & underwater & & & \\
\hline & & 2. & $\begin{array}{l}\text { rescue properly } \\
\text { Using the }\end{array}$ & $\begin{array}{l}\text { environmental } \\
\text { conditions }\end{array}$ & & & \\
\hline & & & technique of & Hovering & V & & \\
\hline & & & landing and & technique is & & & \\
\hline & & & sliding under & suitable for & & & \\
\hline & & & the water with & underwater & & & \\
\hline & & & precision & $\begin{array}{l}\text { environmental } \\
\text { conditions }\end{array}$ & & & \\
\hline & & & & The technique & V & & \\
\hline & & & & of landing & & & \\
\hline & & & & under water & & & \\
\hline & & & & Technique & V & & \\
\hline
\end{tabular}

After designing the learning activity, it is then explained in the Flipped Classroom activity with a cooperative approach which is illustrated with a description of student learning activities as in Tabel 3.

Table 3. Flipped Classroom with a cooperative approach to Diving Environment Training

\begin{tabular}{|c|c|c|c|c|}
\hline \multirow{3}{*}{ Subject } & \multicolumn{4}{|c|}{ Flipped Classroom } \\
\hline & \multicolumn{2}{|c|}{ Outside Class / Asynchronous } & \multicolumn{2}{|c|}{ In Classroom / Synchronous } \\
\hline & Independent & Group & Independent & Group \\
\hline $\begin{array}{l}\text { Underwater } \\
\text { environment }\end{array}$ & $\begin{array}{l}\text { Learn via online } \\
\text { material }\end{array}$ & $\begin{array}{l}\text { deepening through } \\
\text { assignments }\end{array}$ & - & $\begin{array}{l}\text { Participants } \\
\text { analyze all }\end{array}$ \\
\hline $\begin{array}{l}\text { The basics of the } \\
\text { waves and the } \\
\text { movement of the } \\
\text { currents }\end{array}$ & $\begin{array}{l}\text { Learn via online } \\
\text { material }\end{array}$ & $\begin{array}{l}\text { deepening through } \\
\text { assignments }\end{array}$ & - & $\begin{array}{l}\text { assignments based } \\
\text { on the conditions } \\
\text { of their respective } \\
\text { work areas }\end{array}$ \\
\hline $\begin{array}{l}\text { Characteristics of } \\
\text { coral reefs }\end{array}$ & $\begin{array}{l}\text { Learn via online } \\
\text { material }\end{array}$ & $\begin{array}{l}\text { deepening through } \\
\text { assignments }\end{array}$ & - & \\
\hline Biota under water & $\begin{array}{l}\text { Learn via online } \\
\text { material }\end{array}$ & $\begin{array}{l}\text { deepening through } \\
\text { assignments }\end{array}$ & - & \\
\hline $\begin{array}{l}\text { Entry and entry } \\
\text { techniques during } \\
\text { a dive }\end{array}$ & - & - & $\begin{array}{l}\text { Learn by } \\
\text { demonstration }\end{array}$ & $\begin{array}{l}\text { Apply with Field } \\
\text { Practice }\end{array}$ \\
\hline $\begin{array}{l}\text { Diving } \\
\text { techniques in } \\
\text { various } \\
\text { underwater } \\
\text { conditions }\end{array}$ & - & - & $\begin{array}{l}\text { Learn by } \\
\text { demonstration }\end{array}$ & $\begin{array}{l}\text { Apply with Field } \\
\text { Practice }\end{array}$ \\
\hline
\end{tabular}

The development stages have produced early learning products, namely web-based applications with the technology used, namely with Moodle as a Learning Management System (LMS) with adjustments to the pedagogical model and strategies applied to the learning design. 
Table 4. Menu on Training with LMS

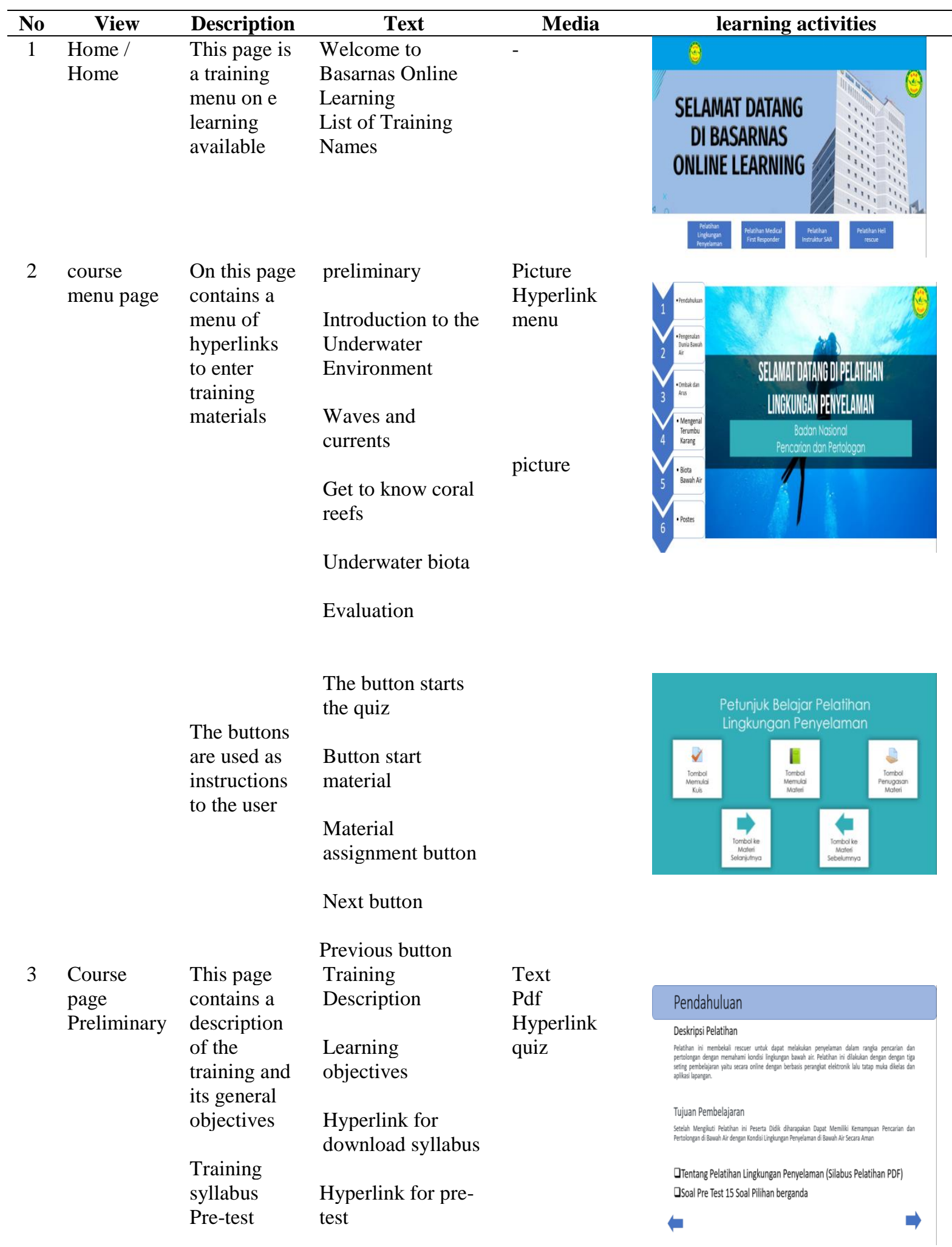




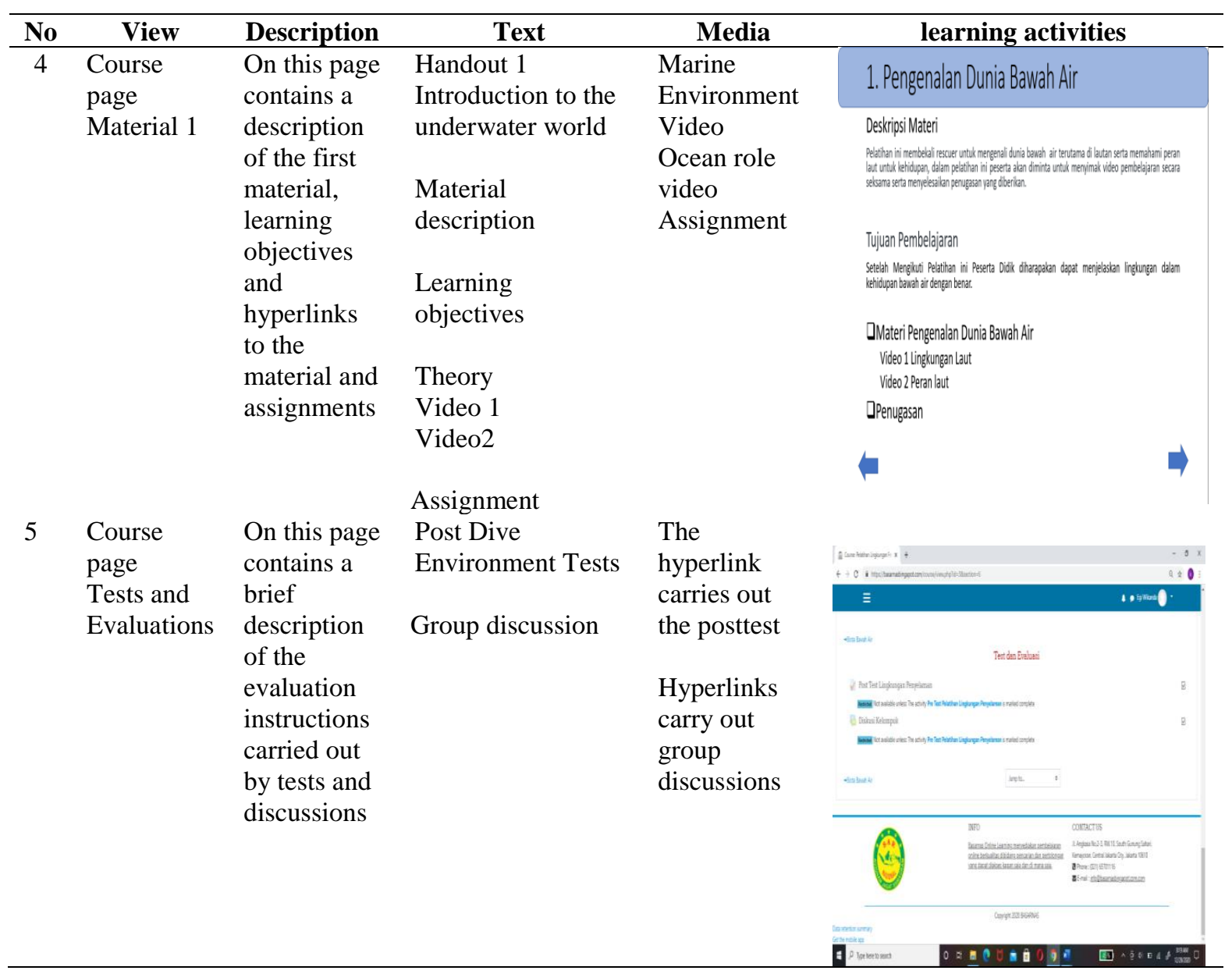

The results of the first assessment have been given by training material experts with a total percentage value of $94.79 \%$ with details of each aspect contained in tabel 5 .

Table 5. Summary of Assessment by Diving Environment training material experts

\begin{tabular}{lccc}
\hline Aspect & Total score & Ideal score & Percentage of Achievement (\%) \\
\hline Learning & 24 & 24 & 100 \\
Theory & 43 & 44 & 97,72 \\
Language and Communication & 24 & 24 & 100 \\
\hline
\end{tabular}

Whereas for the assessment and validation of learning design experts, a percentage value was obtained of $90.27 \%$, with details of each aspect contained in tabel 6 .

Table 6. Recap of assessment by instructional design experts

\begin{tabular}{lccc}
\hline Aspect & Total score & Ideal score & Percentage of Achievement $(\%)$ \\
\hline Learning & 33 & 36 & 91,66 \\
Display & 13 & 16 & 81,25 \\
Language and Communication & 19 & 20 & 95 \\
\hline
\end{tabular}

For assessment and validation by instructional media experts, the percentage of the total value is $90.38 \%$ with details of each aspect contained in tabel 7 . 
Table 7. Recap of learning media expert assessment

\begin{tabular}{lccc}
\hline \multicolumn{1}{c}{ Aspect } & Total score & Ideal Score & $\begin{array}{c}\text { Percentage of Achievement } \\
(\boldsymbol{\%})\end{array}$ \\
\hline Learning & 12 & 12 & 100 \\
Media Display & 24 & 28 & 85,71 \\
Program / Compatibility & 21 & 24 & 87,5 \\
Presentation of materials and media & 37 & 40 & 92,5 \\
\hline
\end{tabular}

The validation test for users is carried out on employees who occupy positions as rescuers and meet the requirements to take part in training consisting of three participants carried out simultaneously, following the total assessment results obtained as shown in tabel 8.

Table 8. Ratings by users in Individual Test (one to one Evaluation)

\begin{tabular}{|c|c|c|}
\hline No & Participant & Value (percentage) $(\%)$ \\
\hline 1 & Participant 1 & 91,66 \\
\hline 2 & Participant 2 & 90 \\
\hline 3 & Participant 3 & 88,33 \\
\hline
\end{tabular}

The next step after obtaining data on the results of individual trials, then testing is carried out on small groups of users to obtain the validation data listed in tabel 9.

Table 9. Ratings by users in the Small group Evaluation

\begin{tabular}{|c|c|c|}
\hline No & Participant & Value (percentage) (\%) \\
\hline 1 & Participant 1 & 96,66 \\
\hline 2 & Participant 2 & 96 \\
\hline 3 & Participant 3 & 93,33 \\
\hline 4 & Participant 4 & 98,33 \\
\hline 5 & Participant 5 & 86,66 \\
\hline 6 & Participant 6 & 88,33 \\
\hline & Average & 93,21 \\
\hline
\end{tabular}

From the results of the assessment and validation both by experts and by users, it can be interpreted, namely the results of the due diligence by material experts for the training material, namely $94.79 \%$, which indicates a very valid level with conclusions that can be used without revision. Meanwhile, learning design experts get a score of 90.27 which if converted is a very valid qualification, and is feasible to use without revision. For instructional media experts give a total value of $90.38 \%$ with the interpretation that learning products can be used without revision. It can be concluded that the Flipped Classroom with a cooperative approach to environmental training can be applied.

This is due to several factors, namely as follows, First, the Flipped Classroom with a cooperative approach can be applied to environmental training because this flipped classroom follows a systematic flow so that learning becomes effective and efficient. Flipped classroom can be used by students anywhere and anytime so that it becomes effective and efficient (Fitriana, 2017; Usman, 2018). Flipped classroom utilizes technology to facilitate students in learning. This approach reverses the learning activities that are traditionally carried out in the classroom and will take place outside the classroom and in the classroom (Foldnes, 2016; Sojayapan \& Khlaisang, 2018). Flipped classroom allows students to get lesson material before learning begins by studying individually or in groups which are usually assisted by learning media such as videos (Kurniawati, Santanapurba, \& Kusumawati, 2019). Media or teaching materials will be uploaded before class learning begins. Thus, students who do not understand the subject matter will be able to repeat it again. When learning in class can be used by instructors to ensure students' understanding.

Second, the Flipped Classroom with a cooperative approach can be applied to training in a diving environment to make learning conditions comfortable and enjoyable. this leads to increased student motivation in learning. (Arianti, 2017; Widodo, 2016) also states that pleasant learning conditions will improve students' ability to understand and accept learning material so that it affects student learning outcomes. This learning activity is indeed very appropriate when applied to training institutions that are constrained by distance. Blended learning with the Flipped Classroom model is learning that combines learning delivery strategies using face-toface activities, computer-based learning (offline), and online computers with the internet (Ceylan, 2017; 
Purnomo et al., 2016; Wulandari et al., 2020). So that the Flipped Classroom is suitable for solving these problems.

These results are similar to other studies that this learning is more effective and efficient with cost and time and can be applied in various disciplines (Foldnes, 2016; Hwang, Wu, \& Chen, 2012). Research conducted by Juniantari, Pujawan, \& Widhiasih, (2019) stated that the Flipped Classroom approach can improve students' understanding of the subject matter. Research conducted by Damayanti \& Sutama (2016) stated that the Flipped Classroom approach can improve students' attitudes and learning skills. So it can be concluded that the Flipped Classroom can be applied to improve students' understanding in learning. The implication of this research is that the Flipped Classroom model developed can be applied to help participants who are constrained by distance in training and make it easier for participants to learn so that it can improve student understanding.

\section{Conclusion}

The results of the feasibility test for developing the Flipped Classroom with a cooperative approach to diving environment training according to material experts, learning designs, and learning media are very well qualified without any revision. It can be concluded that the development of the Flipped Classroom with a cooperative approach to diving environment training can be applied in the learning process.

\section{References}

Akbar, S. (2013). Instrumen Perangkat Pembelajaran. Bandung: Rosdakarya.

Arianti. (2017). Urgensi lingkungan belajar yang kondusif dalam mendorong siswa belajar aktif. Didaktika Jurnal Kependidikan, 11(1), 41-62. https://doi.org/http://dx.doi.org/10.30863/didaktika.v11i1.161

Ceylan, A. (2017). Effect of Blended Learning to Academic Achievement. Journal of Human Sciences, 14(1), 308-320. Retrieved from https://online-journals.org/index.php/i-jet/article/view/3220

Chaeruman, U. (2017). Pedati Model Desain Sistem Pembelajaran Blended. Jakarta: Ristekdikti.

Dahniar, A. (2019). Memahami Pembentukan Sikap (Attitude) Dalam Pendidikan Dan Pelatihan. Tatar Pasundan : Jurnal Diklat Keagamaan, 13(2), 202-206. https://doi.org/10.38075/tp.v13i2.27

Damayanti, \& Sutama. (2016). Efektivitas Flipped Classroom Terhadap Sikap Dan Ketrampilan Belajar Matematika Di SMK. Jurnal Managemen Pendidikan, 11(2). https://doi.org/https://doi.org/10.23917/jmp.v11i1.1799

Darmayasa, I. W. G. S., Suara, I. M., \& Manuaba, I. B. S. (2013). Penerapan Model Pembelajaran Kooperatif Tipe Two Stay Two Strayberbantuan Media Gambar Untuk Meningkatkan Motivasi Dan Hasil Belajar PKn. MIMBAR PGSD Undiksha, 1(1). https://doi.org/http://dx.doi.org/10.23887/jjpgsd.v1i1.922

Dziuban, C., Graham, C. R., Moskal, P. D., Norberg, A., \& Sicilia, N. (2018). Blended Learning: The New Normal and Emerging Technologies. International Journal of Educational Technology in Higher Education, 15(3), 1-16.

Elizar, \& Tanjung, H. (2018). Pengaruh Pelatihan, Kompetensi, Lingkungan Kerja Terhadap Kinerja Pegawai. Maneggio: Jurnal Ilmiah Magister Manajemen, $1(1), \quad 46-58$. https://doi.org/10.30596/maneggio.v1i1.2239

Fitriana, N. (2017). Penerapan Model Pembelajaran Blended Learning Pada Mata Kuliah Pemisahan Kimia Materi Kromatografi Untuk Meningkatkan Kualitas Belajar. Journal of Educational Inovation, 4(1), 46-54. Retrieved from https://erudio.ub.ac.id/index.php/erudio/article/view/210

Foldnes, N. (2016). The flipped classroom and cooperative learning: Evidence from a randomised experiment. SAGE Journal, 17(1). https://doi.org/https://doi.org/10.1177\%2F1469787415616726

Hikmawati, \& Fathan. (2019). Implementasi digital assurance dalam peningkatan mutu pendidikan di sastra Inggris IAIN Surakarta. Jurnal https://doi.org/https://doi.org/10.25078/jpm.v5i1.721

Hwang, G. J., Wu, P. H., \& Chen, C. C. (2012). An online game approach for improving students' learning performance in web-based problem-solving activities. Computers and Education, 59(4), 1246-1256. https://doi.org/10.1016/j.compedu.2012.05.009

Juniantari, M., Pujawan, I. G. N., \& Widhiasih, I. D. A. G. (2019). Pengaruh Pendekatan Flipped Classroom Terhadap Pemahaman Konsep Matematika Siswa SMA. Journal of Education Technology. 
https://doi.org/10.23887/jet.v2i4.17855

Kalantarrashidi, S. A., Mohammadpour, E., \& Sahraei, F. (2015). Effect of Blended Learning Classroon Environment on Student's Satisfaction. Journal of Educaion and Training Studies, 3(5), 225-230. https://doi.org/https://doi.org/10.11114/jets.v3i5.1013

Kurniawati, M., Santanapurba, H., \& Kusumawati, E. (2019). Penerapan Blended Learning Menggunakan Model Flipped Classroom Berbantuan Google Classroom Dalam Pembelajaran Matematika SMP. Jurnal Pendidikan Matematika, 7(1), 8-19. https://doi.org/http://dx.doi.org/10.20527/edumat.v7i1.6827

Kurtz, G., Tsimerman, A., \& Steiner, O. (2014). The Flipped Classroom Answer to Future Learning? European Journal of Open, Distance and E-Learning, 17(2). https://doi.org/https://doi.org/10.2478/eurodl-20140027

Lee, A., \& Owens. (2004). Multimedia-based Instructional Design. California: Pfeiffer.

Megawati, M., \& Riastini. (2014). Pengaruh Model Pembelajaran Kooperatif Tipe Inside Outside Circle (IOC) Terhadap Hasil Belajar IPA Siswa Kelas V Tahun Pelajaran 2013/2014 di Gugus VII Kecamatan Sawan. MIMBAR PGSD Universitas Pendidikan Ganesha Jurusan PGSD, 2(1). https://doi.org/http://dx.doi.org/10.23887/jjpgsd.v2i1.2450

Purnomo, Ratnawati, \& Aristin. (2016). Pengembangan Pembelajaran Blended Learning Pada Generasi Z. JTP2JPS, 1(1). https://doi.org/http://dx.doi.org/10.17977/um022v1i12016p070

Raditya, \& Widhiyani. (2018). Pengaruh budaya organisasi, dukungan manajemen puncak, dan pemanfaatan teknologi informasi pada kinerja sistem informasi akuntansi. E-Jurnal Akuntansi, 24(2), 845-870. https://doi.org/https://doi.org/https://doi.org/10.24843/EJA.2018.v24.i02.p02

Rochmad, R., \& Ulinnuha, R. (2020). Blended learning Menggunakan Gnomio untuk Meningkatkan Kemampuan Berpikir Kreatif Matematis Siswa SMP. PRISMA, Prosiding Seminar Nasional Matematika, $\quad 3, \quad 476-481 . \quad$ Retrieved https://journal.unnes.ac.id/sju/index.php/prisma/article/view/37647

Sojayapan, \& Khlaisang. (2018). The effect of a flipped classroom with online group investigation on students' team learning ability. Kasetsart Journal of Social Sciences, 30(1). Retrieved from https://so04.tcithaijo.org/index.php/kjss/article/view/229130

Soni, Hafid, Hayami, Fatma, Wenando, Amien, ... Mukhtar. (2018). Optimalisasi Penggunaan Google Classroom, E-Learning \& Blended Learning sebagai Media Pembelajaran Bagi Guru dan Siswa di SMK Negeri 1 Bangkinang. Jurnal Pengabdian Untukmu Negeri, 21. https://doi.org/https://doi.org/10.37859/jpumri.v2i1.361

Usman. (2018). Komunikasi Pendidikan Berbasis Blended Learning Dalam Membentuk Kemandirian Belajar. Jurnal Jurnalisa, 4(1), 136-150. https://doi.org/https://doi.org/10.24252/jurnalisa.v4i1.5626

Widodo, W. (2016). Wujud Kenyamanan Belajar Siswa, Pembelajaran Menyenangkan, Dan Pembelajaran Bermakna Di Sekolah Dasar. Ar-Risalah, 18(2), 22-37. Retrieved from http://ejournal.iaiibrahimy.ac.id/index.php/arrisalah/article/view/123/137

Wulandari, Sudatha, \& Simamora. (2020). Pengembangan Pembelajaran Blended Pada Mata Kuliah Ahara Yoga Semester II di IHDN Denpasar. Jurnal Edutech Undiksha, 8(1), 1-15. https://doi.org/http://dx.doi.org/10.23887/jeu.v8i1.26459

Yayuk, \& Sugiyono. (2019). Pengaruh kepemimpinan kepala sekolah dan biaya pendidikan terhadap kualitas proses belajar mengajar dan dampaknya dengan kompetensi lulusan SMK di kabupaten Gunungkidul. Jurnal Akuntabilitas Manajemen Pendidikan, 7(1), 84-96. https://doi.org/https://doi.org/10.21831/amp.v7i1.23758

Yusny, \& Yasa. (2019). Mengembangkan (Pembelajaran) Blended Learning Dengan Sistem Lingkungan Pembelajaran Virtual (VLE) DI PTKIN. Jurnal Ilmiah Islam Futura, 19(1), 103-127. https://doi.org/10.22373/jiif.v19i1.3707

Yusuf, I., \& Widyaningsih, S. W. (2018). Implementasi Pembelajaran Fisika Berbasis Laboratorium Virtual terhadap Keterampilan Proses Sains dan Persepsi Mahasiswa. Berkala Ilmiah Pendidikan Fisika, 6(1), 18. https://doi.org/10.20527/bipf.v6i1.4378 